\title{
FACULTATIVE ALTITUDINAL MOVEMENTS BY MOUNTAIN WHITE-CROWNED SPARROWS (ZONOTRICHIA LEUCOPHRYS ORIANTHA) IN THE SIERRA NEVADA
}

\author{
Thomas P. Hahn, ${ }^{1,5}$ Keith W. Sockman, ${ }^{2}$ Creagh W. Breuner, ${ }^{3}$ \\ and Martin L. Morton ${ }^{4}$ \\ ${ }^{1}$ Center for Animal Behavior and Section of Neurobiology, Physiology and Behavior, University of California Davis, \\ Davis, California 95616, USA; \\ ${ }^{2}$ Department of Biology, University of North Carolina, Chapel Hill, North Carolina 27599, USA; \\ ${ }^{3}$ Integrative Biology, University of Texas at Austin, Austin, Texas 78712, USA; and \\ ${ }^{4}$ Department of Biology, Occidental College, Los Angeles, California 90041, USA
}

\begin{abstract}
Aвstract.-Mountain White-crowned Sparrows (Zonotrichia leucophrys oriantha) winter in Mexico and often arrive in the vicinity of their breeding grounds in the Sierra Nevada well before nesting is possible. Arrival at Tioga Pass, California (elevation 3,030 m), usually occurs in early May, but residual winter snow and adverse weather can delay nesting for weeks. We used radiotelemetry to determine whether prebreeding Mountain White-crowned Sparrows engaged in weather-related altitudinal movements during the waiting period between the end of spring migration and onset of breeding during 1995-2001, with a range of residual winter snowpacks. Interannual variation in arrival date and onset of egg laying was 18 and 41 days, respectively. We tracked females for two years and males for all seven years. During spring snowstorms (which occurred in four years), radiomarked individuals moved to lower elevation sites, where they often remained for several days. Departing birds left Tioga Pass by early afternoon and returned early in the morning after storms. More frequent storms during tracking increased the likelihood of facultative altitudinal movements, but heavier residual winter snowpack did not. Warm days increased the likelihood of birds returning to Tioga Pass from low elevation. This study demonstrates that facultative altitudinal movement behavior can be a common feature of spring arrival biology in montane-breeding birds. Received 1 November 2002, accepted 30 June 2004.
\end{abstract}

Resumen. - Zonotrichia leucophrys oriantha pasa el invierno en México y usualmente llega a las cercanías de sus sitios reproductivos en la Sierra Nevada bastante antes de que sea posible anidar. La llegada a Tioga Pass, California (elevación 3030 m) ocurre usualmente a principios de mayo, pero la presencia de nieve residual del invierno y las condiciones adversas del clima pueden demorar el anidamiento por semanas. Usamos radio-telemetría para determinar si los individuos pre-reproductivos de Z. l. oriantha realizaron movimientos altitudinales inducidos por el clima durante el período de espera entre el final de la migración de primavera y el comienzo de la reproducción durante 1995-2001, considerando un rango de niveles de acumulación de nieve residual del invierno. La variación interanual en la fecha de llegada y en el comienzo de la puesta de huevos fue de 18 y 41 días, respectivamente. Seguimos a las hembras durante dos años y a los machos durante los siete años del estudio. Durante las tormentas de nieve de la primavera (que tuvieron lugar en cuatro años), los individuos marcados con radios se desplazaron a sitios a elevaciones más bajas, donde permanecieron por lo general por varios días. Las aves se marcharon de Tioga Pass a comienzos de la tarde y regresaron temprano en la mañana luego de las tormentas. Una mayor frecuencia de tormentas durante el período de seguimiento de las aves incrementó la probabilidad de que los individuos realizaran movimientos facultativos, pero mayores acumulaciones de nieve residual no tuvieron el mismo efecto. Los días cálidos incrementaron la probabilidad de que las aves regresaran a Tioga Pass desde elevaciones bajas, lo cual demuestra que el comportamiento de movimientos facultativos de los individuos puede ser un rasgo característico de la biología de la llegada de primavera en aves que se reproducen en las montañas.

${ }^{5}$ E-mail: tphahn@ucdavis.edu 
Migratory birds generally must adjust to environmental unpredictability when they arrive on their breeding grounds. This is particularly true for ground and low-shrub nesters breeding in extreme environments, such as high elevations and high latitudes. Winter snowpack determines when nesting and foraging habitat will become available; access can be immediate upon arrival from spring migration or delayed for weeks following arrival. In addition, spring and early summer weather is notoriously capricious in both mountain and Arctic regions. Spring storms can further reduce food availability by covering thawed areas and by hiding arthropods and seeds that accumulate on the surface of existing snow (see Edwards 1972, 1986; Edwards and Banko 1976). Those limitations on food availability, combined with energetically taxing conditions owing to subfreezing ambient temperatures and wind, may press small birds to abandon breeding areas temporarily in favor of relatively benign refugia (see Wingfield et al. 1983). For mountain birds, attractive locations may be available nearby at low elevations, where springlike conditions prevail despite stormy weather in adjacent high country. Consequently, mountain birds can escape inclement weather on breeding grounds through short flights downslope. When those movements between high and low elevations occur seasonally, they are generally termed “altitudinal migrations" (Orr 1970, Dingle 1980; see also Rabenold and Rabenold 1985, Inouye et al. 2000). However, facultative altitudinal movements could theoretically occur whenever weather conditions deteriorate.

Evidence that mountain birds make facultative altitudinal movements prior to or during the breeding season comes primarily from observations of montane, subalpine, and alpine species at low elevations during storms ( $\mathrm{O}^{\prime}$ Neill and Parker 1978, Horvath and Sullivan 1988, Fjeldså 1991, Morton 2002). However, documentation of the phenomenon, especially from monitoring of marked individuals, has been lacking. Consequently, we have little information regarding the nature or prevalence of conditions that induce such behavior. During a long-term study of Mountain White-crowned Sparrows (Zonotrichia leucophrys oriantha) breeding on the central Sierra Nevada crest of California, Morton (2002) occasionally observed color-banded birds from the Tioga Pass population at lower elevations during periods of extreme weather in the 1980s. In 1995, we began a multi-year radiotelemetry study to explore the prevalence of facultative altitudinal movements by Mountain White-crowned Sparrows of the same population. Our results demonstrate that, far from being unusual, facultative altitudinal movements following spring return from Mexico are a common feature of arrival and settlement behavior of both sexes in this population.

\section{Materials ANd Methods}

Study site and study animals. - We conducted the study at Tioga Pass $\left(37^{\circ} 50^{\prime} \mathrm{N}, 119^{\circ} 10^{\prime} \mathrm{W} ; 3,030 \mathrm{~m}\right.$ elevation), in the eastern-central Sierra Nevada of California, and in the Mono Basin immediately to the east ( 2,000 m elevation), the site of a long-term study of Mountain White-crowned Sparrows begun in 1968 (Morton 2002). Habitat around Tioga Pass consists of moist montane and subalpine meadows surrounded by montane coniferous forest, talus slopes, and alpine regions at higher elevations $(\leq 4,000 \mathrm{~m}$; see Morton 2002). Nearby low-elevation habitat in the Mono Basin is dry shrubsteppe.

Mountain White-crowned Sparrows winter in Mexico (Cortopassi and Mewaldt 1965) and typically begin arriving at Tioga Pass in early to mid-May. At that time, feeding and nesting habitat in the montane and subalpine zones may be partially or wholly free of snow (Fig. 1A), or may remain completely covered by a meter or more of snow (Fig. 1B). Weather during May and early June can be severe and unpredictable, and new snowfall that covers all available foraging areas is frequent. As a consequence of fluctuations in residual winter snowpack and spring weather, onset of egg laying in the population varies interannually by as much as eight weeks (Morton 1978, 2002).

The steep eastern Sierra slope permits sparrows to reach phenologically advanced sites $\geq 600 \mathrm{~m}$ lower in elevation (Fig. 1C) with very short flights (a few kilometers, compared with hundreds of kilometers to the wintering grounds in Mexico; Fig. 2). Snow accumulation during May storms often occurs as low as 2,400 m, but only rarely reaches as low as Mono Lake $(2,000 \mathrm{~m})$. Even when spring snow accumulates in Lee Vining Canyon and the Mono Basin, foraging sites beneath thick shrubs usually remain accessible to ground-feeding birds.

Temperature records. - We collected hourly temperature records at Tioga Pass using Hobo temperature loggers (Onset Computer Corporation, Pocasset, Massachusetts) placed in the shade $2 \mathrm{~m}$ above ground in a dense clump of pines.

Trapping. - We captured sparrows in potter traps baited with small amounts of seed (millet). Dates of first capture were considered dates of arrival from 

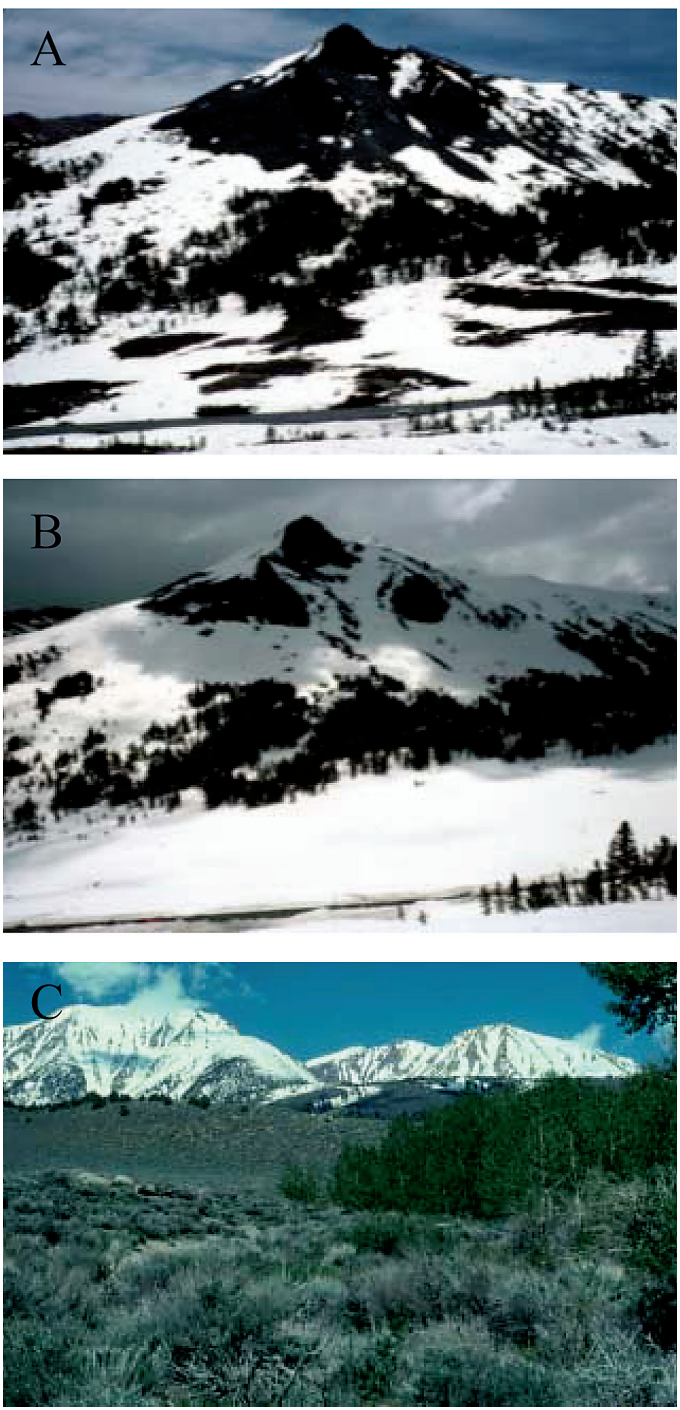

Fig. 1. (A) Photograph of the main study area at Tioga Pass (3,000 m elevation) taken on 1 June 1997, a relatively light snow year. Note snow-free patches, which include subalpine willows and scrub pines; the first egg of the season was laid on that day. Snow melt was proceeding rapidly, and 50\% snow cover was reached four days after the photograph was taken (5 June). (B) Same view of Tioga Pass as in (A), on 7 June 1998, a heavy snow year. Note that subalpine willow and scrub-pine nesting sites are still almost entirely covered with snow remaining from winter. The strip of snow-free area across the bottom of the photograph is highway 120 (plowed). The first egg was not laid until 26 June-more than three weeks later than in 1997, and 50\% snow cover was not reached until 6 July, a full month later than in 1997. (C) Low-elevation
Mexico. We always began trapping before any females had arrived on the study area, but a few males were already present when trapping began in some years. Consequently, we present arrival schedules as date of capture of the 10th new male and of the 1st female.

Telemetry. - We fitted sparrows with small (1.1 g) radiotransmitters (Advanced Telemetry Systems, Isanti, Minnesota; a few transmitters came from Wildlife Materials, Carbondale, Illinois), each broadcasting on a unique frequency. We attached transmitters in 1995 by a glue-down technique (see Chandler et al. 1994); in all other years, we used an elastic thread harness around the legs (the only modification from Rappole and Tipton [1991] was use of elastic thread).

Following attachment of transmitters, we assessed presence or absence of birds during each day, after dark, and often before first light at Tioga Pass. We used two R2000 programmable receivers with collapsible three-element directional yagi antennas (ATS, Isanti, Illinois). It is unlikely that a signal from a radiomarked bird actually present on the study area would not be detected. Signals absent during a scan were almost always from (1) individuals known to be at a specific distant site at lower elevation, or (2) individuals that were consistently and repeatedly absent during a series of scans from multiple locations around Tioga Pass. Individuals that were repeatedly missing and later determined to have been alive and carrying a functioning transmitter were considered to have been "absent" from Tioga Pass at the time in question, even if their actual whereabouts were unknown.

We often tracked birds at low elevation on foot until we found the bird and confirmed its identity by its unique combination of colored leg bands. In most cases, however, we either estimated locations by triangulation or simply plotted them roughly on the basis of the direction from which we obtained a signal from a given scanning location. We were primarily interested in whether birds were "up" (at Tioga Pass) or "down" (at some lower-elevation refuge) at any given time; signals from transmitters at Tioga Pass are never detectable from low-elevation scan sites, nor vice versa.

White-crowned Sparrows very rarely remove radiotransmitters attached with harnesses, which

$\leftarrow$

refuge habitat at the base of the eastern slope of the Sierra, a few kilometers east of Tioga Pass ( 2,200 m elevation), photographed on 6 June 1995, a very heavy snow year. Note that deciduous trees, such as quaking aspen (Populus tremuloides), are already in full leaf; snow cover at Tioga Pass was still $100 \%$ when the photograph was taken, and 50\% snow cover was not reached until 18 July. Site shown was used repeatedly by one female Mountain White-crowned Sparrow (F4 in Fig. 4) during snow storms in spring 1995. 


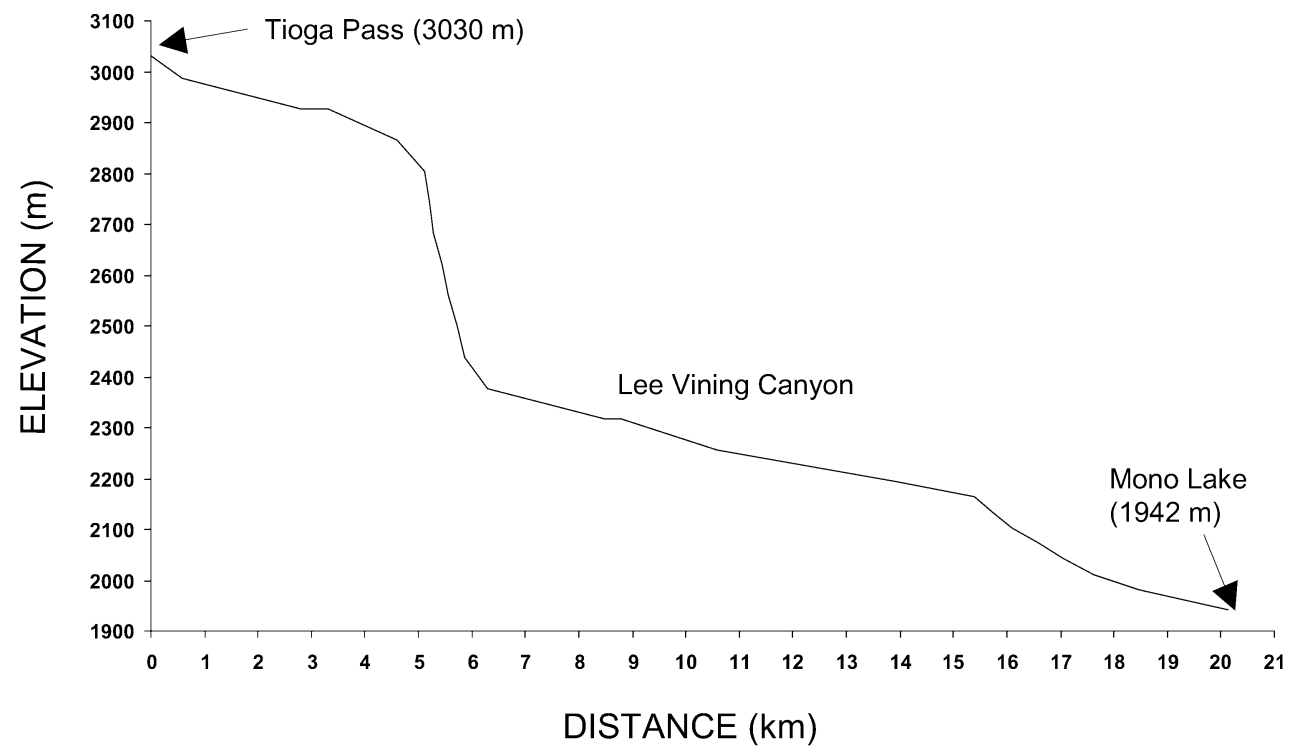

Fig. 2. Elevational profile from Tioga Pass to Mono Lake. Profile follows the path of Lee Vining Creek off the eastern escarpment. It does not display high peaks $(>4,000 \mathrm{~m}$ elevation) that lie in the direct west-east path from Tioga Pass to Mono Lake.

raises the possibility that a telemetry record where the bird was not observed directly could be for a transmitter discarded by a bird. We include only records where subsequent capture or direct observation confirmed that the radiotransmitter was still on the bird.

\section{Results}

Conditions during years of the study. - Residual winter snowpack, spring weather, vegetation phenology, and Mountain White-crowned Sparrow arrival and nesting schedules varied substantially among the seven years of the study (Table 1). Snowpack on 1 April (date after which melt typically exceeds new accumulation) varied from well below the 75-year average in 2001 to near the highest on record in 1995. New snowfall during tracking was absent in some years (1999 and 2001) and frequent in others $(1995,1996$, and 1998). Date of arrival of the 10th male ranged from 5 to 22 May, and that of the 1st female from 6 to 23 May. Date of first egg for the population ranged from 28 May to 7 July. Both arrival and egg laying closely tracked phenological changes in the environment $(50 \%$ snow cover date and peak wild-onion [Allium sp.] flowering date; Fig. 3), as previously reported for the population (Morton 1994).

Prevalence and description of facultative altitudinal movements.-Our results are based on radiotracking of 57 male and 14 female Mountain White-crowned Sparrows during prebreeding periods of seven consecutive years (1995-2001, Table 1; females were tracked only in 1995 and 1996). In four of those years (1995, 1996, 1998, and 2000), all but one of the radiomarked males departed Tioga Pass at least once during monitoring (in 1998, a single male never left). The 1 April snowpack in those four years ranged from just below the 75-year average (2000) to the third highest on record (1995), and significant snow storms occurred during May and sometimes June of all four of those years. In the remaining three years (1997, 1999, and 2001), none of the radiomarked males ever departed. Spring weather was consistently benign in all three of those years, and 1 April snowpacks ranged from well below to just above average (Table 1$)$.

When Mountain White-crowned Sparrows left Tioga Pass, most moved well down Lee Vining Canyon or even out into the Mono Basin. Our best data on exact low-elevation locations used come from 1995, when we made particular efforts to find missing birds. In that year, males tended to move down into Lee Vining Canyon, whereas females went farther out into the Mono Basin (Fig. 4). Individual birds often visited the same lowelevation locations each time they left Tioga Pass. 

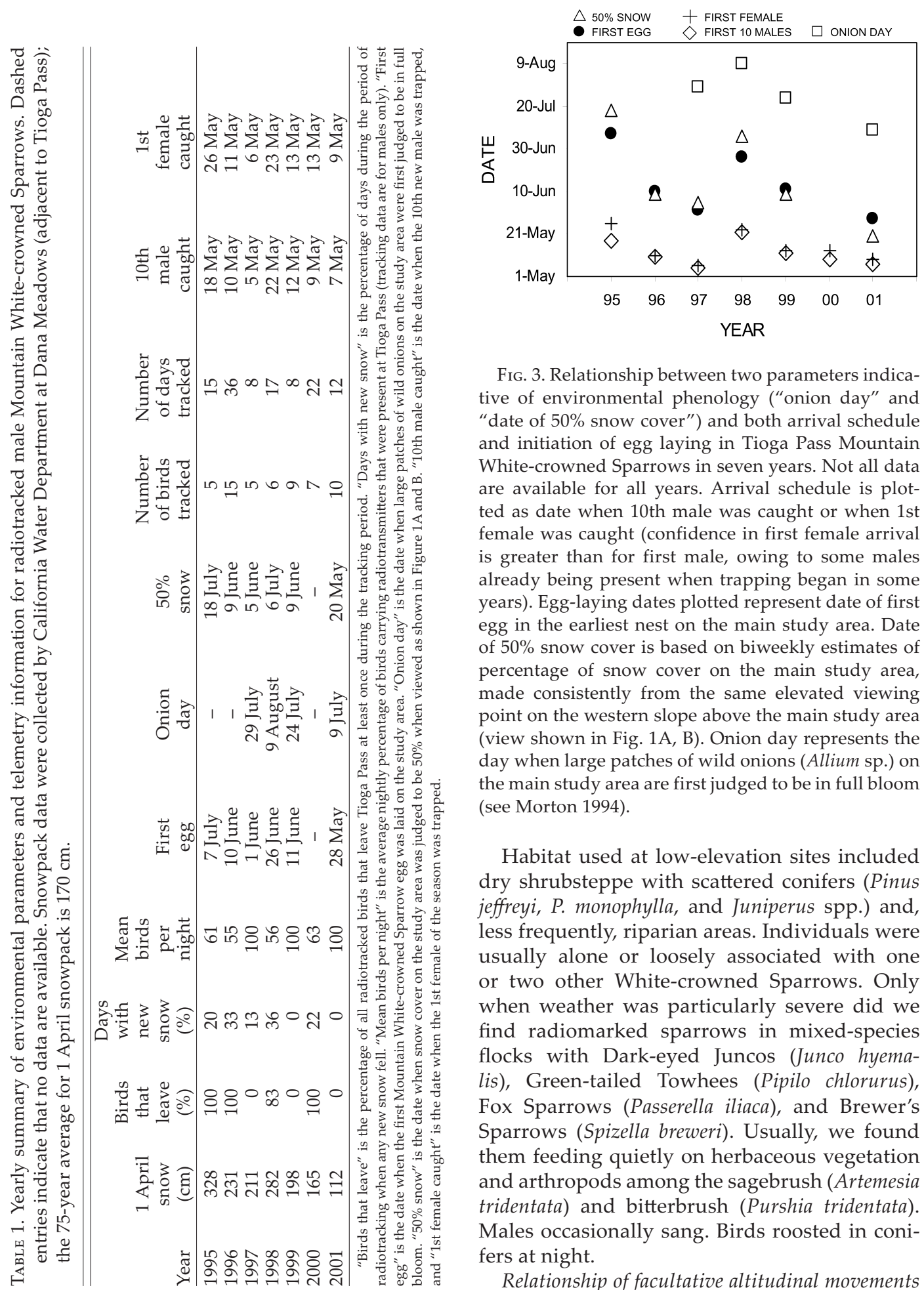

FIG. 3. Relationship between two parameters indicative of environmental phenology ("onion day" and "date of 50\% snow cover") and both arrival schedule and initiation of egg laying in Tioga Pass Mountain White-crowned Sparrows in seven years. Not all data are available for all years. Arrival schedule is plotted as date when 10th male was caught or when 1st female was caught (confidence in first female arrival is greater than for first male, owing to some males already being present when trapping began in some years). Egg-laying dates plotted represent date of first egg in the earliest nest on the main study area. Date of $50 \%$ snow cover is based on biweekly estimates of percentage of snow cover on the main study area, made consistently from the same elevated viewing point on the western slope above the main study area (view shown in Fig. 1A, B). Onion day represents the day when large patches of wild onions (Allium sp.) on the main study area are first judged to be in full bloom (see Morton 1994).

Habitat used at low-elevation sites included dry shrubsteppe with scattered conifers (Pinus jeffreyi, P. monophylla, and Juniperus spp.) and, less frequently, riparian areas. Individuals were usually alone or loosely associated with one or two other White-crowned Sparrows. Only when weather was particularly severe did we find radiomarked sparrows in mixed-species flocks with Dark-eyed Juncos (Junco hyemalis), Green-tailed Towhees (Pipilo chlorurus), Fox Sparrows (Passerella iliaca), and Brewer's Sparrows (Spizella breweri). Usually, we found them feeding quietly on herbaceous vegetation and arthropods among the sagebrush (Artemesia tridentata) and bitterbrush (Purshia tridentata). Males occasionally sang. Birds roosted in conifers at night.

Relationship of facultative altitudinal movements to weather.-During our study, prevalence of 


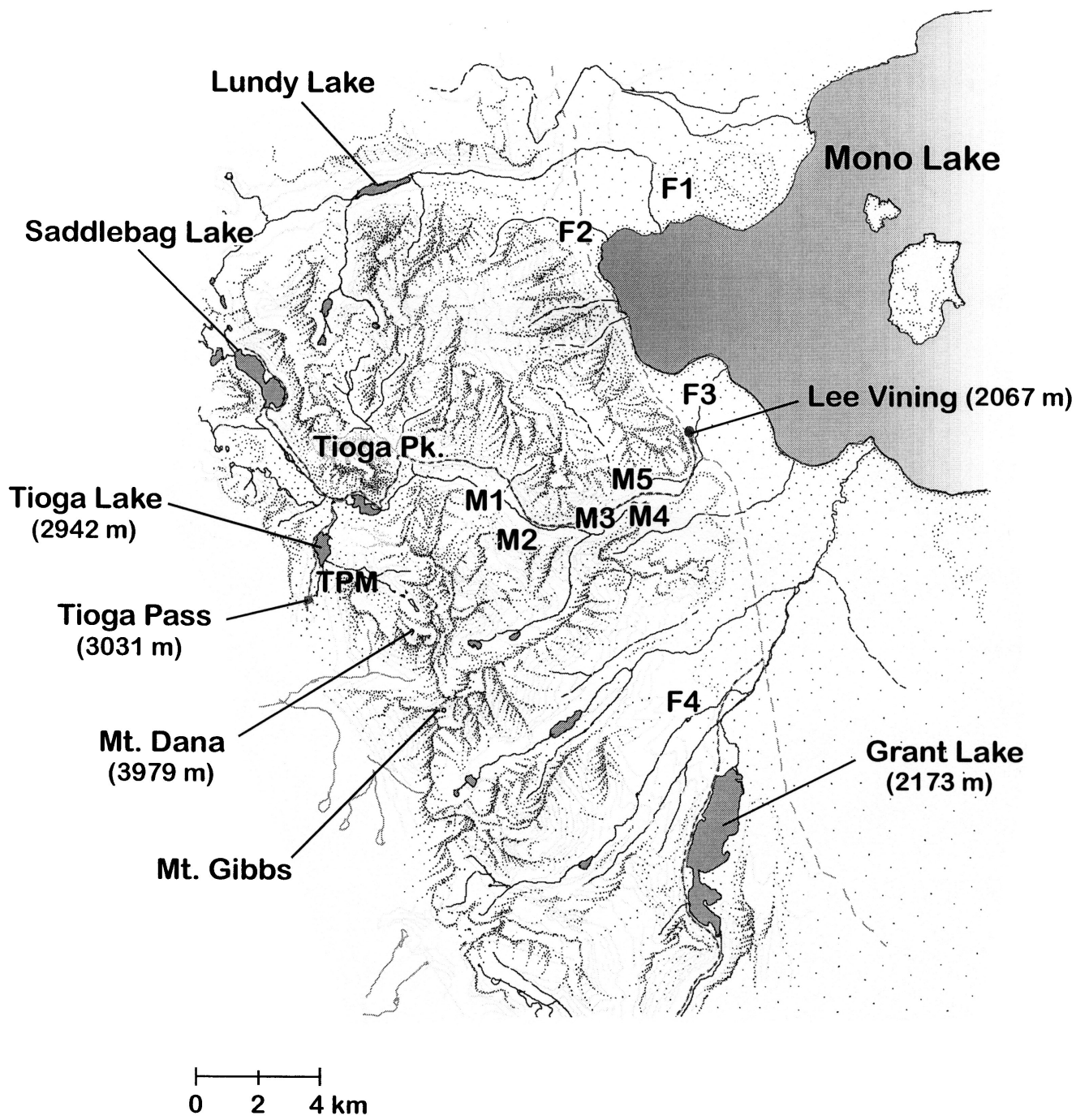

FIG. 4. Map of low-elevation refugia positions in 1995, the year of the study with the heaviest residual winter snowpack. Females are indicated by F1-F4, and males by M1-M5. Sites plotted are those used repeatedly by each individual. Note that site F4 is the location of the photograph in Figure 1C. (TPM = Tioga Pass Meadow.)

facultative altitudinal movements was greatest in years when more new snow fell after the birds arrived; it was not significantly related to residual winter snowpack (Table 1). Multiple regression using the mean nightly percentage of birds roosting at Tioga Pass in each year (percentages on Tioga Pass; percentages arcsine transformed) as the dependent variable, and residual winter snowpack (1 April snow) and percentage of sampled days when new snow fell (new snow; arcsine transformed) as independent variables, produced a significant regression overall, but a slope different from zero only for new snow (regression equation: percentage at Tioga Pass $=106-0.029$ (1 April snow) - 1.317 (new snow); adjusted $R^{2}=0.829$, 
$F=9.710, \mathrm{df}=2$ and $4, P=0.029 ; t_{1 \text { April snow }}=$ $-0.363, P=0.735$; $\left.t_{\text {new snow }}=-3.328, P=0.029\right)$. In other words, birds were significantly less likely to roost at Tioga Pass (i.e. more likely to engage in facultative altitudinal movements) the more often it snowed after they arrived, but they were not significantly less likely to roost at Tioga Pass simply because more snow remained on the ground from winter storms.

Importance of facultative altitudinal movements in arrival biology of the birds is best illustrated by a detailed description of the phenomenon in a year when weather was unsettled and birds moved frequently. In 1996, residual winter snowpack was above average, weather during May was stormy, and we were equipped to radiotrack a particularly large number of individuals of both sexes. Figure 5 presents proportion of radiotagged Mountain Whitecrowned Sparrows visiting Tioga Pass during the day $(\mathrm{A}, \mathrm{B})$ or spending the night there $(\mathrm{C}$, $\mathrm{D})$, with temperature records and incidence of storms (E) from 5 May (day before arrival of first male, 99\% snow cover) through 9 June 1996 (day before first egg was laid; $50 \%$ snow cover). Birds of both sexes clearly tended to remain away from Tioga Pass when weather was stormy and return when weather improved.

Relationships between behavior and ambient temperature.-Figure 5 suggests that in 1996, Mountain White-crowned Sparrows were most likely to be at low elevations when ambient temperatures were low and at Tioga Pass when ambient temperatures were high. We used a forward-stepping multiple regression to examine the relationship between temperature and tendency of birds to return to Tioga Pass or to stay there if already present (Table 2). We also produced scatter plots of the data (Fig. 6A-C). Sexes were treated separately in statistical analysis, but scatter plots combine both sexes (statistical results for males and females were qualitatively identical; see Table 2 and below). We tested models relating proportion of birds present at Tioga Pass during the day to date, maximum temperature reached that day (Fig. $6 \mathrm{~A})$, and minimum temperature reached the previous night (Fig. 6B). Dates after 1 June (when all birds returned permanently to Tioga Pass) were excluded from the regression analysis but are included in the figures. We tested models relating proportion of birds roosting at Tioga Pass at night to date, minimum temperature reached
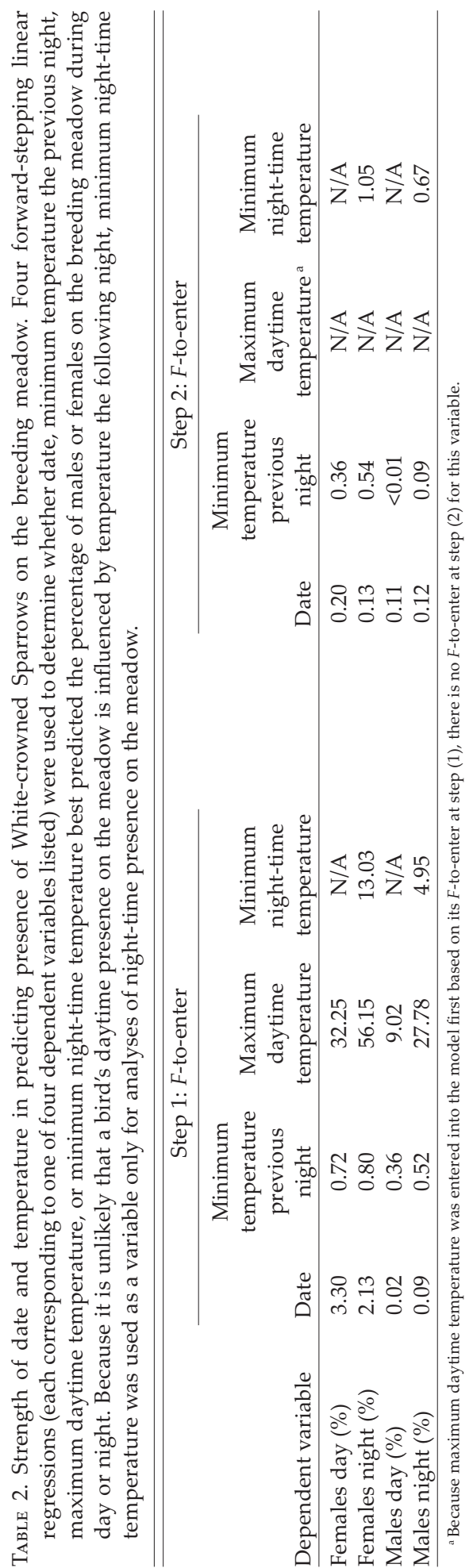


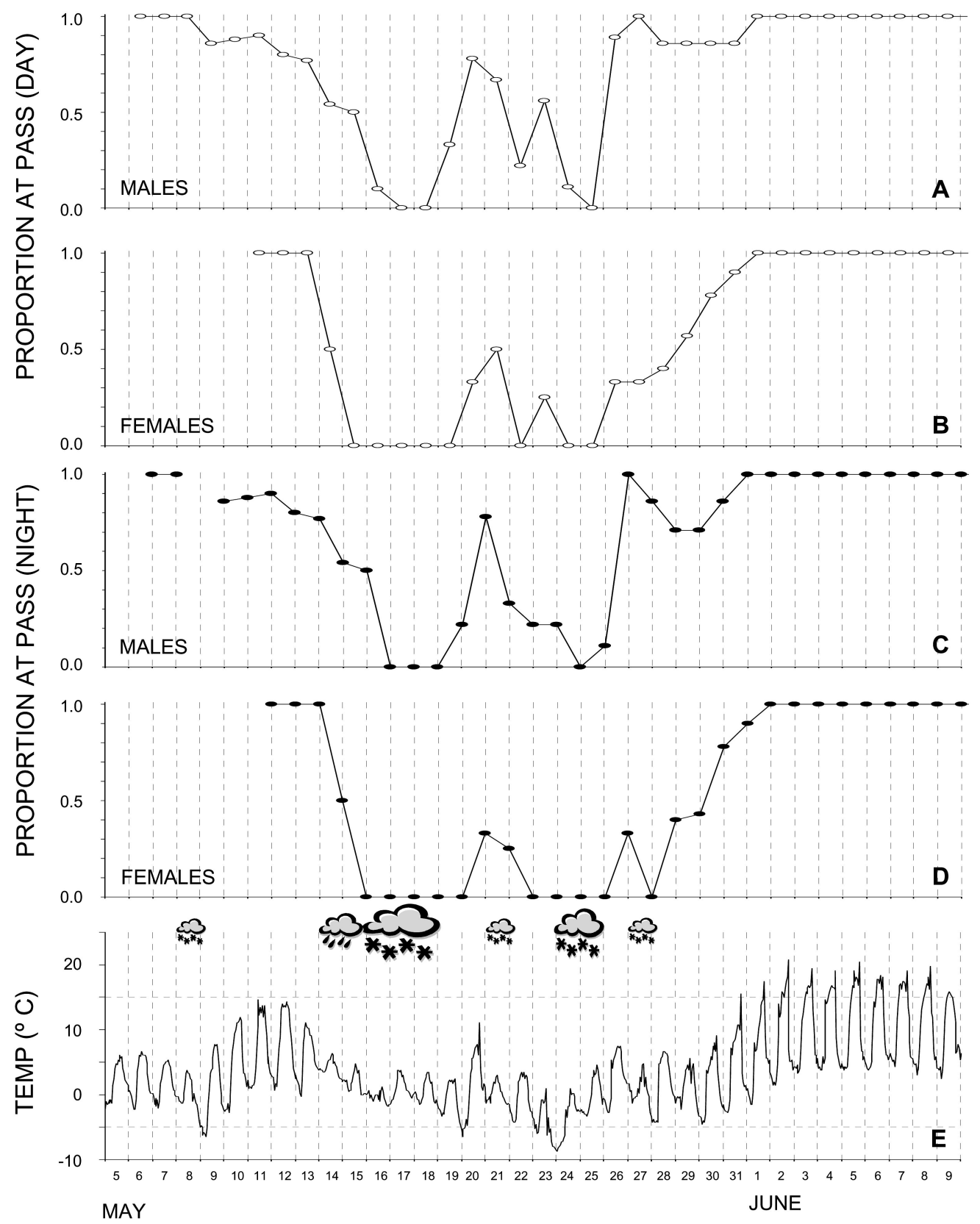

Fig. 5. Prevalence of radiotagged Mountain White-crowned Sparrows at Tioga Pass during May and early June 1996, as functions of ambient temperature and weather at Tioga Pass. Top two panels (A and B: open circles) plot proportions of males and females at Tioga Pass during the day; next two panels (C and D: opaque circles) plot proportions spending the night there. Bottom panel (E) plots ambient temperature measured hourly in a cluster of pines in the middle of the study area. Rain and snow clouds indicate periods of adverse weather, overall size of clouds reflects general severity of storms, and widths of clouds span dates of precipitation. Numbers of radiomarked males were 1 on 6 May, 4 on 7 May, and 7-13 on all remaining dates plotted. Numbers of radiomarked females were 1 on 11-12 May, 2 on 13-19 May, and 3-10 on all remaining dates plotted. 


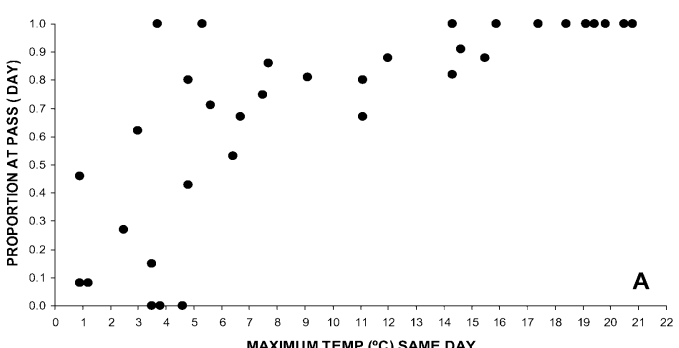

MAXIMUM TEMP $\left({ }^{\circ} \mathrm{C}\right)$ SAME DAY
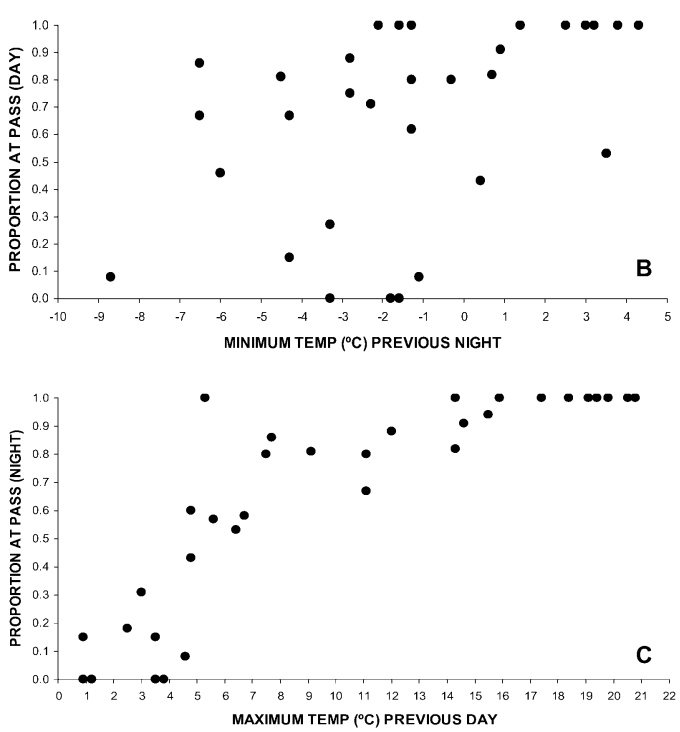

FIG. 6. Relationship between proportion of radiotagged Mountain White-crowned Sparrows (both sexes combined) at Tioga Pass and ambient temperature there (1996 data only). (A, B) Proportion of birds at least visiting Tioga Pass during the day (not necessarily staying there all day) as functions of the maximum temperature reached that same day (A), and minimum temperature the night before (B). (C) Proportion of birds roosting at Tioga Pass at night as a function of the minimum temperature the night before. Proportions are based on the same sample sizes as for Figure 5.

the previous night, maximum temperature reached during the day just ended (Fig. 6C), and minimum temperature eventually reached that night. The strong relationship between daytime high temperature and proportion of birds at Tioga Pass that day and that night evident in Figure 6A and 6C, respectively, is borne out by the multiple regression. Maximum daytime temperature was clearly the best predictor of proportion of birds of both sexes at Tioga Pass both during the day and that night (Table 2; high Step 1 F-to-enter values). None of the other factors were significant predictors of the proportion of birds at Tioga Pass after variation explained by maximum daytime temperature was removed (Table 2; uniformly low Step 2 F-to-enter values).

\section{Discussion}

We have demonstrated that Mountain Whitecrowned Sparrows of the central Sierra Nevada frequently engage in altitudinal movements between arrival from vernal migration and onset of nesting. The behavior is facultative, depending on environmental conditions, but is clearly an important component of the birds' tactics for dealing with conditions at high elevations. Interindividual variation requires further study, but may depend on age, sex, territory quality, body condition, stress physiology, reproductive condition, and individual coping styles. To our knowledge, the present study is the clearest demonstration of the behavior to date, and the first that tracks the activities of individual birds over time.

Factors regulating facultative altitudinal movements.-Inclement weather is responsible for Mountain White-crowned Sparrows leaving the breeding area for lower elevation, and they usually do not return until the weather improves. However, that generalization raises the question of precisely what factors related to weather function as proximate cues affecting behavioral decisions. Most of the answers to that question await further study, but we can suggest several possibilities that may, alone or in combination, serve to influence the birds' behavior. External factors, such as ambient temperature, precipitation, barometric pressure, residual snow cover, and food availability, could act as direct cues stimulating departure or return behavior. Internal factors, such as body condition, stress hormones, and reproductive hormones, could serve as mediators or modulators of the birds' responses to external cues. We have sufficient data to discuss several of those possibilities briefly.

\section{Residual Winter SNowpack}

Residual winter snow cover seems a logical determinant of facultative altitudinal movements. A large residual snowpack conceals the 
vast majority of open ground where Mountain White-crowned Sparrows prefer to forage for weeks longer than a small snowpack does. Consequently, we expected that in heavy snowpack years, birds would make daily trips between the breeding area and more-productive foraging areas at nearby low elevations just to the east. Data presented here suggest otherwise. Mountain White-crowned Sparrows were not any less likely to spend the night at Tioga Pass in heavy residual winter-snowpack years than in light ones. This suggests that recent arrivals to Tioga Pass find enough to eat on patches of bare ground or on the surface of the snow, where arthropods carried on air currents from lower elevations accumulate (see Edwards 1987). We commonly observed Mountain White-crowned Sparrows feeding in those locations. New snowfall can cover the limited bare ground and conceal the widely spaced food items present on the surface of older snow, and new snowfall is apparently the primary trigger for facultative altitudinal movements in Mountain Whitecrowned Sparrows. An interaction between storm severity and residual winter snowpack would be detectable only with precise quantification of amounts of new spring snowfall, which we did not attempt in the present study.

\section{Temperature}

Our data on the role of temperature are mixed. Birds may have been using daytime temperature to decide whether or not to stay at high elevation over night. However, when birds at low elevations returned to Tioga Pass, they did so very early in the morning, around the time of the previous night's minimum temperature (see also Breuner and Hahn 2003). Minimum temperature reached the night before was a poor predictor of the proportion of birds present on Tioga Pass on a given day. Thus, data are consistent with birds using temperature to decide whether to stay at high elevation, but not consistent with their using it to decide whether to return to high elevation from low elevation. If temperature is being used as a cue to regulate behavioral decisions, we suspect that it does so in concert with other cues.

\section{Other FACTORS}

It seems plausible that Mountain Whitecrowned Sparrows are sufficiently observant to simply detect deteriorating or improving conditions and to decide, based on that information, to leave for low elevation or to return to high elevation. It is notable, however, that tendency to depart or return on any given day varied substantially among individuals, which suggests that even if direct observation of the weather is involved, the response is modulated by other factors, such as body condition or food availability. Individuals occupying territories on south-facing slopes along streams are generally the last to leave when weather conditions deteriorate. Those territories have the first open ground in spring and accumulate the least snow during spring storms. Moreover, preliminary data from an experimental study indicate that individuals with access to weatherprotected feeders never depart for low elevation during snowstorms that drive all other birds down (C. W. Breuner and T. P. Hahn unpubl. data). Consequently, we currently favor the hypothesis that weather does not act directly but affects other factors (e.g. body condition and stress physiology through reducing access to food or increasing thermoregulation costs) that influence behavior directly (Breuner and Hahn 2003).

Despite limitations on our ability to determine precise timing of birds' departures from and arrivals at Tioga Pass (e.g. owing to road closures during storms), our data nevertheless demonstrate substantial interindividual variation in behavioral responses to weather. Except during the most extreme weather (subfreezing ambient temperatures, high winds, heavy snowfall), Mountain White-crowned Sparrows differed in their decision whether to be at high or at low elevation. That interindividual variation promises to be valuable in evaluating potential roles of different external factors (e.g. amount of snow cover on particular birds' territories, severity of storms), internal factors (e.g. body condition, stress response physiology), and individual-specific differences (e.g. coping styles) in regulating facultative altitudinalmovement behavior.

Why wait? - The present study underscores a phenomenon that we have long found fascinating: Mountain White-crowned Sparrows wait for sites at high elevations to open up in years with heavy residual snowpack, rather than settling to breed at lower elevation. We do not think this is because no lower-elevation sites are 
suitable. Mountain White-crowned Sparrows breed abundantly at much lower elevations in habitats similar to those used only as refugia by the Tioga Pass birds; for example, in sagebrush flats in the Warner Mountains of northeastern California (2,250 m elevation; T. P. Hahn pers. obs.) and at Hart Mountain in southeastern Oregon (1,900 m elevation; Walsberg and King 1978). Sage meadows in the lower Lee Vining Canyon, east of Tioga Pass, appear qualitatively similar to those areas populated by breeding Mountain White-crowned Sparrows farther north. If White-crowned Sparrows settled in those sage flats, they could begin breeding weeks earlier than they do at Tioga Pass. That would be particularly advantageous in heavy snow years, some of which (e.g. 1995) delayed breeding at the Sierra crest so drastically that the birds were in danger of becoming photorefractory before they even had a chance to lay their first clutch of eggs. Reasons (both proximate and ultimate) for that apparent inflexibility are currently unknown. One possible proximate explanation is that the Tioga Pass birds imprint on subalpine habitat as youngsters and subsequently refuse to consider lower-elevation habitats nearby for breeding (Morton et al. 1991). Perhaps, competition with lower-elevation species such as Greentailed Towhees is involved, possibly from both ultimate and proximate perspectives.

Generality of facultative altitudinal movements. - What most impresses us is that this behavior is not something that occurs only sporadically. Though highly plastic and contingent on environmental conditions, facultative altitudinal movements are clearly a normal feature of the arrival biology of Mountain White-crowned Sparrows living at Tioga Pass. We suspect that the entire guild of migratory species that breed in the High Sierra likewise make regular use of facultative altitudinal movements to cope with capricious spring mountain weather. We frequently observed groups of Dark-eyed Juncos at low elevations when we found our radiomarked Mountain White-crowned Sparrows there during storms. Telemetry data from one of the most extreme mountain specialists of the region, Gray-crowned Rosy-finches (Leucosticte tephrocotis dawsoni), indicate that they often moved to low elevations during spring snowstorms (M. Richardson pers. comm.).

Facultative altitudinal movement is likely a particularly tractable option for birds breeding on the Sierra Nevada crest, owing to the precipitous elevation drop down the eastern escarpment. Although the birds' proximity to low-elevation refugia may represent an extreme case, such situations are common in mountain areas throughout the world, and most mountain birds can probably usually escape adverse conditions in the high country by flying relatively short distances to lower elevations. Some environments may not afford birds the same degree of behavioral flexibility, however. Escape from adverse spring weather at high latitudes may require relatively long, energetically costly reverse migrations (see Gauthreaux 1980). Similar problems could face birds breeding on high plateau regions, as in central Asia, where escape to low elevations may require long-distance movements. We expect birds breeding in such areas to have evolved somewhat different tactics for coping with poor spring weather. For example, they should arrive relatively later, when the risk of life-threatening storms is lower (see Iwasa and Levin 1995 for theoretical treatment of this issue), and carry relatively heavier fat deposits after arrival to provide a larger buffer against periods of storm-related low food supply and high thermoregulation demands.

Although facultative altitudinal movement as described here must be restricted to birds that live at least part of the year at high elevations, it is really only a conspicuous form of a more general type of behavior that is widespread among migratory birds. That is, seasonal migrants and even relatively sedentary species tend to initiate or extend movements flexibly, depending on the specific environmental conditions they experience (Gauthreaux 1980, Terrill 1987, Terrill and Able 1988). In many cases, movements may not be as dramatic as the facultative altitudinal movements displayed by Sierra Nevada Mountain White-crowned Sparrows, but they would likely be no less critical to the birds' survival of adverse environmental conditions (e.g. Wingfield et al. 1983, Wingfield 1985). On the other hand, irruptive movements in response to unpredictable changes in food supply can be far more impressive than the facultative altitudinal movements we describe here. Irruptive migrants, such as many species that rely on masting tree species, can move hundreds or even thousands of kilometers outside their usual geographic ranges when conditions warrant (Svärdson 1957, James 1967, Bagg 
1969, Newton 1973, Bock and Lepthein 1976). Thus, studying the factors affecting-and mechanisms regulating - facultative altitudinal movements may illuminate similar processes in a wide variety of birds.

\section{Acknowledgments}

We thank S. Oppenheimer, M. Katti, and E. A. MacDougall-Shackleton for assistance with field work; M. E. Pereyra for assistance with preparation of figures; R. L. Wylie for assistance with preparation of the manuscript; and H. Dingle, J. Buler, N. T. Wheelwright, and an anonymous reviewer for comments on the manuscript. We also thank the U.S. Fish and Wildlife Service, the California Department of Fish and Game, and the United States Department of Agriculture, Forest Service, for their permission to conduct these studies. Financial support for the work was provided by the Frank M. Chapman Memorial Fund, Princeton University; the University of Texas at Austin; and the University of California Davis.

\section{Literature Cited}

BAGG, A. M. 1969. A summary of the fall migration season, 1968, with special attention to the movements of Black-capped Chickadees. Audubon Field Notes 23:4-12.

Bock, C. E., AND L. W. Lepthien. 1976. Synchronous eruptions of boreal seed-eating birds. American Naturalist 110:559-571.

Breuner, C. W., and T. P. Hahn. 2003. Integrating stress physiology, environmental change, and behavior in free-living sparrows. Hormones and Behavior 43:115-123.

Chandler, C. R., E. D. Ketterson, V. Nolan, Jr., AND C. Ziegenfus. 1994. Effects of testosterone on spatial activity in free-ranging male Darkeyed Juncos, Junco hyemalis. Animal Behaviour 47:1445-1455.

Cortopassi, A. J., and L. R. Mewaldt. 1965. The circumannual distribution of White-crowned Sparrows. Bird-Banding 36:141-169.

Dingle, H. 1980. Ecology and evolution of migration. Pages 1-101 in Animal Migration, Orientation, and Navigation (S.A. Gauthreaux, Jr., Ed.). Academic Press, New York.

EDWARDS, J. S. 1972. Arthropod fallout on Alaskan snow. Arctic and Alpine Research 4:167-176.

EDWARDS, J. S. 1986. Derelicts of dispersal: Arthropod fallout on Pacific Northwest volcanoes. Pages 196-203 in Insect Flight: Dispersal and Migration (W. Danthanarayana, Ed.). Springer Verlag, Berlin.

EDWARDS, J. S. 1987. Arthropods of alpine aeolian ecosystems. Annual Review of Entomology 32: 163-179.
Edwards, J. S., ANd P. C. Banko. 1976. Arthropod fallout and nutrient transport: A quantitative study of Alaskan snowpatches. Arctic and Alpine Research 8:237-245.

FJELDSA, J. 1991. The activity of birds during snow-storms in high-level woodlands in Peru. Bulletin of the British Ornithologists' Club 111: 4-11.

Gauthreaux, S. A., Jr. 1980. The influences of longterm and short-term climatic changes on the dispersal and migration of organisms. Pages 103-174 in Animal Migration, Orientation, and Navigation (S. A. Gauthreaux, Jr., Ed.). Academic Press, New York.

Horvath, E. G., and K. A. Sullivan. 1988. Facultative migration in Yellow-eyed Juncos. Condor 90:482-484.

Inouye, D. W., B. Barr, K. B. Armitage, and B. D. Inouye. 2000. Climate change is affecting altitudinal migrants and hibernating species. Proceedings of the National Academy of Sciences USA 97:1630-1633.

Iwasa, Y., AND S. A. Levin. 1995. The timing of lifehistory events. Journal of Theoretical Biology 172:33-42.

James, F. C. 1967. Central southern region. Audubon Field Notes 21:426-430.

Morton, M. L. 1978. Snow conditions and the onset of breeding in the Mountain Whitecrowned Sparrow. Condor 80:285-289.

Morton, M. L. 1994. Comparison of reproductive timing to snow conditions in wild onions and White-crowned Sparrows at high altitude. Great Basin Naturalist 54:371-375.

Morton, M. L. 2002. The Mountain White-crowned Sparrow: Migration and reproduction at high altitude. Studies in Avian Biology, no. 24.

Morton, M. L., M. W. Wakamatsu, M. E. Pereyra, and G. A. Morton. 1991. Postfledging dispersal, habitat imprinting, and philopatry in a montane, migratory sparrow. Ornis Scandinavica 22:98-106.

Newton, I. 1973. Finches. Taplinger, Englewood Cliffs, New Jersey.

O'Neill, J. P., and T. A. PArker III. 1978. Responses of birds to a snowstorm in the Andes of southern Peru. Wilson Bulletin 90:446-449.

OrR, R. T. 1970. Animals in Migration. MacMillan, New York.

Rabenold, K. N., and P. P. Rabenold. 1985. Variation in altitudinal migration, winter segregation, and site tenacity in two subspecies of Dark-eyed Juncos in the southern Appalachians. Auk 102:805-819.

Rappole, J. H., ANd A. R. Tipton. 1991. New harness design for attachment of radio transmitters to small passerines. Journal of Field Ornithology 62:335-337. 
Svärdson, G. 1957. The invasion type of bird migration. British Birds 50:314-343.

Terrill, S. B. 1987. Social dominance and migratory restlessness in the Dark-eyed Junco (Junco hyemalis). Behavioral Ecology and Sociobiology 21:1-11.

Terrill, S. B., AND K. P. Able. 1988. Bird migration terminology. Auk 105:205-206.

Walsberg, G. E., And J. R. King. 1978. The heat budget of incubating Mountain Whitecrowned Sparrows (Zonotrichia leucophrys oriantha) in Oregon. Physiological Zoology 51:92-103.
Wingfield, J. C. 1985. Influences of weather on reproductive function in male Song Sparrows, Melospiza melodia. Journal of Zoology (London) 205:525-544.

Wingfield, J. C., M. C. Moore, and D. S. Farner. 1983. Endocrine responses to inclement weather in naturally breeding populations of White-crowned Sparrows (Zonotrichia leucophrys pugetensis). Auk 100:56-62.

Associate Editor: F. R. Moore 